\title{
Spatial distribution and abundances of ammonia-oxidizing archaea (AOA) and ammonia-oxidizing bacteria (AOB) in mangrove sediments
}

\author{
Meng Li • Huiluo Cao • Yiguo Hong • Ji-Dong Gu
}

Received: 7 May 2010 /Revised: 27 September 2010 / Accepted: 28 September 2010 /Published online: 16 October 2010

(C) The Author(s) 2010. This article is published with open access at Springerlink.com

\begin{abstract}
We investigated the diversity, spatial distribution, and abundances of ammonia-oxidizing archaea (AOA) and ammonia-oxidizing bacteria (AOB) in sediment samples of different depths collected from a transect with different distances to mangrove forest in the territories of Hong Kong. Both the archaeal and bacterial amoA genes (encoding ammonia monooxygenase subunit A) from all samples supported distinct phylogenetic groups, indicating the presences of niche-specific AOA and $\mathrm{AOB}$ in mangrove sediments. The higher AOB abundances than AOA in mangrove sediments, especially in the vicinity of the mangrove trees, might indicate the more important role of AOB on nitrification. The spatial distribution showed that AOA had higher diversity and abundance in the surface layer sediments near the mangrove trees $(0$ and $10 \mathrm{~m})$ but lower away from the mangrove trees $(1,000 \mathrm{~m})$, and communities of AOA
\end{abstract}

Electronic supplementary material The online version of this article (doi:10.1007/s00253-010-2929-0) contains supplementary material, which is available to authorized users.

M. Li $\cdot$ H. Cao $\cdot$ J.-D. Gu $(\bowtie)$

School of Biological Sciences, The University of Hong Kong,

Pokfulam Road,

Hong Kong, SAR, People's Republic of China

e-mail: jdgu@hkucc.hku.hk

\section{Y. Hong}

Key Laboratory of Tropical Marine Environment Dynamics

(LED), South China Sea Institute of Oceanography,

Chinese Academy of Sciences,

164 Xingang Road West,

Guangzhou 510301, People's Republic of China

J.-D. Gu

Swire Institute of Marine Science, The University of Hong Kong,

Shek O, Cape d'Aguilar,

Hong Kong, SAR, People's Republic of China could be clustered into surface and bottom sediment layer groups. In contrast, AOB showed a reverse distributed pattern, and its communities were grouped by the distances between sites and mangrove trees, indicating mangrove trees might have different influences on AOA and AOB community structures. Furthermore, the strong correlations among archaeal and bacterial amo $A$ gene abundances and their ratio with $\mathrm{NH}_{4}{ }^{+}$, salinity, and $\mathrm{pH}$ of sediments indicated that these environmental factors have strong influences on $\mathrm{AOA}$ and $\mathrm{AOB}$ distributions in mangrove sediments. In addition, AOA diversity and abundances were significantly correlated with hzo gene abundances, which encodes the key enzyme for transformation of hydrazine into $\mathrm{N}_{2}$ in anaerobic ammoniumoxidizing (anammox) bacteria, indicating AOA and anammox bacteria may interact with each other or they are influenced by the same controlling factors, such as $\mathrm{NH}_{4}{ }^{+}$. The results provide a better understanding on using mangrove wetlands as biological treatment systems for removal of nutrients.

Keywords Ammonia-oxidizing archaea (AOA). Ammonia-oxidizing bacteria (AOB) $\cdot$ Community structures · Mangrove sediments · Anammox · hzo gene Abundance $\cdot$ Diversity

\section{Introduction}

Mangrove ecosystems, the important natural wetlands distributed along estuaries in tropical and subtropical region, provide breeding, growing, refuge, and feeding zone for many marine organisms (Holguin et al. 2001). In mangrove ecosystem, microbial activities are the key processes contributing to the high productivity of this 
ecosystem (Holguin et al. 2001). Microbial-mediated nutrient transformation and subsequent export to other marine ecosystems, such as nitrogen and phosphate, are important to mangrove and other coastal ecosystems (Sjoling et al. 2005). For the nitrogen (N) cycle within mangrove ecosystem, microbial processes include dinitrogen $\left(\mathrm{N}_{2}\right)$-fixation, nitrification, denitrification, ammonification, anaerobic ammonium oxidizing (anammox), and dissimilatory nitrate reduction to ammonium (Purvaja et al. 2008). The alternating aerobic and anaerobic conditions caused by tidal flushing in mangrove wetlands provide a suitable environment for the nitrification (Kristensen et al. 1998) and denitrification (Rivera-Monroy and Twilley 1996) or anammox (Meyer et al. 2005), which affects the rate of $\mathrm{N}$ turnover. On the other hand, the mangrove trees could also enhance microbial $\mathrm{N}$ transformation by transporting $\mathrm{O}_{2}$ to the otherwise anoxic subsurface sediment through their aerial roots to support nitrification (Holguin et al. 2001) or providing the carbon source to fuel heterotrophic denitrification in the rhizosphere (Zhu and Sikora 1995); at the same time, mangrove trees may inhibit microbial $\mathrm{N}$ transformation due to the competition for available $\mathrm{N}$ in mangrove ecosystem. These information show that a complex microbial $\mathrm{N}$ transformation exists in a mangrove ecosystem which requires more research efforts to understand the dynamics of theses microorganisms and their contributions to the $\mathrm{N}$ cycle in mangrove ecosystem.

Nitrification, a two-step process that includes the oxidation of ammonium via hydroxylamine to nitrite and then nitrate, is a key process in marine $\mathrm{N}$ cycling. The first and rate-limiting step, ammonia oxidation, is executed by limited number of microbial groups, including aerobic chemoautotrophic bacteria and archaea. Bacterial members include the $\beta$-proteobacteria Nitrosomonas and Nitrosopiras, and the $\gamma$-proteobacteria Nitrosococcus (Purkhold et al. 2000). Both, the amoA genes which encode the catalytic $\alpha$-subunit of the ammonia monooxygenase enzyme and 16S rRNA genes have been used in molecular studies for analyzing ammonia-oxidizing bacteria (AOB) in the environment, specifically to determine the effects on diversity, abundance and community structures by physicochemical parameters, e.g., pH, temperature, oxygen, light, soil management regimes, etc. (Kowalchuk and Stephen 2001; Prosser and Embley 2002). The first ammonia-oxidizing archaeon (AOA) Nitrosopumilus maritimus has been isolated from a marine aquarium tank recently (Konneke et al. 2005). N. maritimus is a representative of the ubiquitous marine "group 1" archaeota and grows chemolithoautotrophically by oxidizing ammonia to nitrite under mesophilic conditions (Konneke et al. 2005). In addition, $N$. maritimus contains putative genes for all three subunits ( $a m o A, a m o B$, and $a m o C$ ) of the ammonia monooxygenase (Konneke et al. 2005). The discovery of ammonia oxidizers in the archaea has inspired many researchers to investigate this new group. Francis et al. (2005) provided the first molecular evidence demonstrating the archaeal amoA gene to be pervasive in the ocean, including the euphotic zone, suboxic water columns and coastal/estuarine sediments. Up to now, the diversity, distribution and physiology of AOA have been widely investigated in soils (Adair and Schwartz 2008; Hansel et al. 2008), seawater column (Francis et al. 2005; Lam et al. 2007; Mincer et al. 2007; Beman et al. 2008), marine sediments (Beman and Francis 2006; Santoro et al. 2008), aquaria filters (Urakawa et al. 2008), rhizosphere (Chen et al. 2008; Herrmann et al. 2008, 2009), municipal sewage plants (Park et al. 2006), hot spring (de la Torre et al. 2008; Hatzenpichler et al. 2008; Zhang et al. 2008), hydrothermal vents, and even marine invertebrates (Steger et al. 2008). Erguder et al. (2009) summarized the current knowledge on the environmental conditions related to the presence of AOA and identified site-related properties and environmental factors which included ammonium, organic carbon, temperature, salinity, oxygen, $\mathrm{pH}$, sulfide, phosphate, and some metal contents. Furthermore, the interactions between nitrifiers (AOA and $\mathrm{AOB})$ and anammox bacteria were also recorded in the Black Sea (Lam et al. 2007) and in the Peruvian oxygen minimum zone (Lam et al. 2009), where nitrifiers were proposed to supply the nitrite to anammox to form a nitrification-anammox coupling.

It is apparent that previous studies have demonstrated convincingly that $\mathrm{AOA}$ and $\mathrm{AOB}$ are widely distributed and regulated by the physiochemical characteristics of environments, but no study has examined AOA and $\mathrm{AOB}$ in mangrove ecosystems. Nitrification rates in mangrove sediments measured by chemical methods indicated that nitrification occurred predominantly close to the sediment surface in micro-oxic zones, which were created by the oxygen-pumping activity of mangrove roots and in the oxidized lining of animal burrows (Holguin et al. 2001; Purvaja et al. 2008). The studies suggested nitrification rates increased generally with depth at the vegetated site, where nitrifiers were subjected to more oxic conditions compared with non-vegetated sediments, indicating the distribution of mangrove plants might have strong influences on nitrification in mangrove ecosystems (Holguin et al. 2001; Purvaja et al. 2008). Constructed and natural mangrove wetlands have been employed as alternative low cost biological systems for treatment of municipal sewage with high inorganic nitrogen, which might be transformed by AOA and AOB (Wong et al. 1997). However, the community structures and distribution of $\mathrm{AOA}$ and $\mathrm{AOB}$, and their relationship with mangrove trees are still largely unknown. In the present study, we report the phylogenetic diversity, distribution and abundance of AOA and $\mathrm{AOB}$ based on archaeal and bacterial amoA genes 
analyses in surface and lower layer sediments collected from different sites located at different distances to mangrove trees in the New Territories of Hong Kong. In addition, the relationships of the diversity, distribution and abundance of $\mathrm{AOA}$ and $\mathrm{AOB}$ with environmental factors, mangrove trees and occurrence of copies of the hzo gene which in anammox bacteria encodes the key enzyme for transformation of hydrazine to $\mathrm{N}_{2}$ and is used as an indicator of anammox activity and potential (Strous et al. 2006; Shimamura et al. 2007; Schmid et al. 2008), were also analyzed using statistical analysis. The results will help us to improve our understanding of the usage of mangrove wetlands as wastewater treatment systems for removal of nutrients.

\section{Materials and methods}

Sample collection and physicochemical analyses

Mai Po Marshes Nature Reserve, located at the northwestern corner of the New Territories of Hong Kong $\left(22^{\circ} 30^{\prime} \mathrm{N}\right.$, $114^{\circ} 02^{\prime} \mathrm{E}$ ), is the largest remaining coastal wetland in Hong Kong. Mai Po Marshes Nature Reserve comprises of subtropical mangroves, inter-tidal mudflats, as well as man-made fishponds and drainage channels. In the mangrove wetland, the dominated mangrove trees are Kandelia obovata (formerly Kandelia candel). The area is quite homogenous and three sampling sites (S0, S1, and S2) were selected in a transect: site S0 was immediately to the mangrove trees in the forest; site $\mathrm{S} 1$ with a distance of $10 \mathrm{~m}$ to the mangrove forest edge, and site $\mathrm{S} 2$ on the inter-tidal mudflats without any mangrove tree or vegetation about $1,000 \mathrm{~m}$ from S0 (Electronic supplementary Fig. 1). The surface layer $(1-2 \mathrm{~cm})$ and lower layer $(20-21 \mathrm{~cm})$ sediment samples were collected in triplicate at each of the three sampling sites and homogenized the triplicate sediment samples into one to represent each site, and all samples were immediately transferred into a $4^{\circ} \mathrm{C}$ cooler for transport to the laboratory for analyses (within $2 \mathrm{~h}$ ). Samples were labeled by the sampling sites (S0-S2) with surface layer (s) or lower layer (1), and obtained sequences in each site were labeled by their site name with clone number.

Temperature, redox potential and $\mathrm{pH}$ of the sediment samples were measured in situ using IQ180G Bluetooth Multi-Parameter System (Hach Company, Loveland, CO) and concentrations of $\mathrm{NH}_{4}{ }^{+}-\mathrm{N}, \mathrm{NO}_{3}{ }^{-}-\mathrm{N}$, and $\mathrm{NO}_{2}{ }^{-}-\mathrm{N}$ in pore water of sediment samples were measured, after centrifugation, with an autoanalyzer (QuickChem, Milwaukee, WI) according to standard methods given by the American Public Health Association (American Public Health Association 1995). Salinity of pore water was measured using a YSI 556 Multiprobe System (YSI, Yellow Springs, $\mathrm{OH}$ ). The results are summarized in the Electronic supplemenatry Table S-1.

DNA extraction, PCR amplification, and cloning

Total genomic DNA of each sediment samples were extracted using the SoilMaster DNA Extraction kit (Epicentre Biotechnologies, Madison, WI), respectively. Archaeal amoA genes were amplified using primers Arch-amoAF (5'-STAATGGTCTGGCTTAGACG-3') and Arch-amoAR (5'-GCGGCCATCCATCTGTATGT-3') (Francis et al. 2005), while bacterial amoA genes were amplified by amoA-1F (5'-GGGGTTTCTACTGGTGGT-3') and amoA-2R (5'-CCCCTCKGSAAAGCCTTCTTC-3') (Rotthauwe et al. 1997). Polymerase chain reaction (PCR) reaction mixtures contained $1 \mu \mathrm{l}$ DNA (30-50 ng $\left.\mu \mathrm{l}^{-1}\right)$, $1 \mu \mathrm{l}$ bovine serum albumin (100 mg ml${ }^{-1}$, Roche), $5 \mu \mathrm{l}$ $10 \times$ GoTaq Flexi buffer (Promega, Hong Kong), and $4 \mu \mathrm{l}$ $\mathrm{MgCl}_{2}$ (25 mM, Promega), $1 \mu \mathrm{l}$ of dNTPs $(5 \mathrm{mM}$, Invitrogen, Hong Kong), $1 \mu$ of each forward and reverse primer $(20 \mu \mathrm{M})$, and $0.25 \mu \mathrm{l}$ of GoTaq Flexi polymerase ( $5 \mathrm{U} \mathrm{\mu l}^{-1}$, Promega, Hong Kong), and the final volume for each reaction was $50 \mu \mathrm{l}$. PCR reactions were performed as follows: $95^{\circ} \mathrm{C}$ for $3 \mathrm{~min} ; 35$ cycles of $95^{\circ} \mathrm{C}$ for $45 \mathrm{~s}, 53^{\circ} \mathrm{C}$ (for AOA) or $55^{\circ} \mathrm{C}$ (for AOB) for $1 \mathrm{~min}$, followed by $72^{\circ} \mathrm{C}$ for $1 \mathrm{~min}$; and finally $72^{\circ} \mathrm{C}$ for $7 \mathrm{~min}$. Triplicate PCR reaction products for each site were pooled; gel purified using Gel Advance-Gel Extraction System (VIOGEME, Taipei) and cloned using the pMD18 T-vector (Takara, Japan), and replicated clone libraries were constructed for each sampling sites for the two layers. The insertion of an appropriate-sized DNA fragment was determined by PCR amplification with the primer set M13F and M13R (Invitrogen, Hong Kong).

Sequencing and phylogenetic analysis

Sequencing was performed with the Big Dye Terminate kit (Applied Sciences, Foster City, CA) and an ABI Prism 3730 DNA analyzer (Applied Biosystems, Foster City, CA). DNA sequences were examined and edited by MEGA 4.0 software (Tamura et al. 2007). In order to obtain reliable phylogenetic results, we carried out the alignment by using identical number of bp for each of the obtained sequences (465 bp for archaeal amoA and $640 \mathrm{bp}$ for bacterial amoA), which were almost the full fragments amplified by the selected primer sets used in our study. Nucleic acid sequences of archaeal and bacterial amo $A$ genes were aligned using the MEGA 4.0 software package, and phylogenetic trees were constructed with the neighborjoining and maximum parsimony methods, and bootstrap re-sampling analysis for 1,000 replicates was performed to 
estimate the confidence of the tree topologies (Tamura et al. 2007).

\section{Quantitative PCR assay}

The copy numbers of amoA gene of AOA and AOB in all sediment samples were determined in triplicate using an ABI 7000 Sequence detection system (Applied Biosystems, Foster City, CA). The quantification was based on the fluorescent dye SYBR-Green I. Each reaction was performed in a $25 \mu \mathrm{l}$ volume containing $1 \mu \mathrm{l}$ of DNA template, $1 \mu \mathrm{BSA}$ (100 mg ml${ }^{-1}$, Roche), $1 \mu \mathrm{l}$ of each primer $(20 \mu \mathrm{M})$ and $12.5 \mu \mathrm{l}$ of Power SYBR-Green PCR Master Mix (Applied Biosystems, Foster City, CA). The PCR protocols were identical as those described above except that the final extension step was omitted and that 50 cycles were performed followed by melting analyses. The hzo gene abundances of anammox bacteria in the same sediment samples were also analyzed by quantitative PCR, and details for the PCR amplification experiments are available elsewhere ( $\mathrm{Li}$ et al. 2010). We used the constructed plasmids carrying the targeted gene sequences ( $a m o A$ or $h z o$ ) as the standards, which were generated by amplifying genes from extracted DNA of site S1-s sediments and cloning them into pMD18 T-vector (Takara, Japan). The abundances of targeted genes in each sample were calculated by the parallel quantitative PCR of different dilutions of the standard plasmids, where copy number of standard plasmids in each dilution could be calculated by their concentrations. The quantitative PCR amplification efficiencies ranged from 0.92-0.96 (AOA amoA), 0.910.95 (AOB amoA) and 0.85-0.92 (hzo), and correlation coefficients $\left(R^{2}\right)$ were greater than 0.99 for the three targeted genes. Comparison for amoA gene abundances of $\mathrm{AOA}$ and $\mathrm{AOB}$ was done by analysis of variance (ANOVA) for definition of any significant differences among these sediment sample sites with their different layers.

\section{Statistical analysis}

To obtain views on the richness and diversity of archaeal and bacterial amoA genes, operational taxonomic units (OTUs) for community analysis were defined by $5 \%$ differences in nucleotide sequences, as determined by using the furthest neighbor algorithm in DOTUR (Schloss and Handelsman 2005). Shannon and Simpson indices for each sampling site were also generated by DOTUR. The community structures of archaeal and bacterial amoA genes between any two clone libraries were compared with LIBSHUFF software version 0.96 (http://libshuff.mib.uga. edu/) to get a quantitative documentation according to the Singleton method (Singleton et al. 2001). To further rigorously examine the geographic distribution of phylogenetic structures of AOA and $\mathrm{AOB}$ in mangrove sediments, the phylogenetic trees derived from the alignment used in Figs. 2 and 3 but restricted to archaeal and bacterial amoA sequences recovered in this study were analyzed by using the principal coordinates analysis (PCoA) and Jackknife Environment Clusters analysis in UniFrac (Lozupone et al. 2006). Finally, correlation analysis of $\mathrm{AOA}$ and $\mathrm{AOB}$ community structures with environmental factors, mangrove trees and anammox bacteria was conducted using Microsoft Excel program with Pearson's moment correlation.

Nucleotide sequence accession numbers

The GenBank accession numbers for the archaeal and bacterial amoA genes sequences reported here are GQ331390-GQ331635 and GQ331636-GQ331908, respectively. The $h z o$ gene accession numbers are GQ331363 to GQ331389.

\section{Results}

Richness and phylogenetic diversity of AOA and AOB

In this study, 246 archaeal and 273 bacterial amoA clones were sequenced from $12 \mathrm{AOA}$ and $\mathrm{AOB}$ clone libraries (Table 1). Within each individual sampling site, two to eight AOA and two to eight AOB OTUs were found. In some cases, such as AOA in S1-s and AOB in S2-s, the OTU numbers would be higher if more clones were sequenced, based on non-asymptotic rarefaction curves (Electronic supplementary Fig. S-2). The highest AOA richness occurred at S1-s, and the lowest occurred in S0-1, while the highest AOB richness occurred at S2-1, and the lowest was $\mathrm{S} 0$-s, consisting with the values of Shannon and Simpson indices. In addition, AOA showed a higher richness at the surface layer in the vicinity of the mangrove tree (S0 and S1); while AOB had higher OTUs at site S2 than $\mathrm{S} 0$ or S1 for both surface and lower layers sediments (Table 1).

Phylogenetic diversity analysis showed that archaeal amoA sequences were divided into five clusters (Fig. 1). Cluster 1 fell into a phylogenetic group comprising a large proportion of archaeal amoA sequences (150 out of 246) and some published sequences recovered from deep sea, bay, or estuary sediments (Dang et al. 2008, 2009). Sequences in clusters 2 and 3 recovered from the surface layer of the research sites were more closely related to those from wastewater treatment plants (Park et al. 2006; Zhang et al. 2009). It was interesting that the sequences in cluster 4 formed a distinct phylogenetic cluster where DNA se- 
Table 1 Diversity characteristics of each clone library of archaeal and bacterial amoA genes in different sample sites

\begin{tabular}{llllll}
\hline amoA gene & Sampling site & Number of screened clones & OTUs & Shannon index & Simpson index \\
\hline \multirow{2}{*}{ AOA } & S0-s & 42 & 6 & 1.51 & 0.25 \\
& S0-1 & 44 & 2 & 0.53 & 0.64 \\
& S1-s & 36 & 8 & 1.60 & 0.24 \\
& S1-1 & 47 & 4 & 0.90 & 0.45 \\
& S2-s & 36 & 3 & 0.55 & 0.74 \\
& S2-1 & 41 & 6 & 1.37 & 0.29 \\
& S0B & 47 & 2 & 0.66 & 0.52 \\
& S0-1 & 45 & 2 & 0.69 & 0.49 \\
& S1-s & 44 & 2 & 0.67 & 0.51 \\
& S1-1 & 44 & 5 & 0.96 & 0.43 \\
& S2-s & 47 & 6 & 1.34 & 0.33 \\
& S2-1 & 46 & 8 & 1.70 & 0.20 \\
\hline
\end{tabular}

quence identity with available amo $A$ sequences was $<88 \%$, indicating new site specific AOA species in mangrove sediments. Approximately $10 \%$ of archaeal amo $A$ clones fell into cluster 5 which related to amo $A$ sequences from Northern California coastal/estuarine sediment (Mosier and Francis 2008) and N. maritimus (Konneke et al. 2005). Comparing with AOA, the phylogeny of AOB was much simpler and all amoA sequences related to Nitrosomonaslike sequences were grouped in three different clusters (Fig. 2). About $41.8 \%$ of sequences in cluster 1 were closely related to the clones recovered from Bahía del Tóbari estuaries, Chesapeake Bay and Jiaozhou Bay (Francis et al. 2003; Beman and Francis 2006). Similar to AOA, a large proportion (148 out of 273) of bacterial amoA sequences also formed a site specific group (cluster 3 ), and the DNA identity with available sequences was less than $89 \%$. Furthermore, three sub-clusters could be identified within cluster 3 , where sequences in two of the three subclusters were recovered only from site S2 and the third group was retrieved from all sampling sites.

amo $A$ and hzo gene abundances in mangrove sediments

AOA amo $A$ gene copy numbers ranged from $6.04 \times 10^{6}$ to $9.45 \times 10^{6}$ copies per dry gram of sediment at surface layers, and the S0 and S1 located near mangrove trees had higher archaeal amoA gene abundances than S2 located far away from mangrove trees. In contrast, AOA amo $A$ gene abundances in lower layer sediments were increasing from S0 to $\mathrm{S} 2$ along with the distances of sampling sites to mangrove trees (Fig. 3a). However, AOB amoA gene abundances were decreasing from $\mathrm{S} 0$ to $\mathrm{S} 2$ at both surface and lower layer sediments, ranging from $0.95 \times 10^{7}$ to $4.17 \times 10^{7}$ copies per dry gram of sediment (Fig. 3b). In addition, AOA amoA gene abundances were higher at surface layer sediments for sites $\mathrm{S} 0$ and $\mathrm{S} 1$ but lower at lower layer sediments for the site S2, while AOB amoA gene abundances showed the opposite $(p<0.05, n=3$, ANOVA). The ratios of bacterial to archaeal amo $A$ genes $(0.87 \pm 0.27$ to $11.93 \pm 0.25)$ indicated that AOB amo $A$ copy numbers were greater than those of AOA in mangrove sediments except in the lower layer of S2, where was far away from mangrove trees (Fig. 3c). Furthermore, the significant different $(p<0.05, n=3$, ANOVA) ratios of AOB/AOA amoA abundance decreased from 5.01 \pm 0.55 to $2.22 \pm 0.69$ at surface layers and $11.93 \pm 0.25$ to $0.86 \pm$ 0.27 at lower layers from sites S0 to S2, respectively, which indicates a striking spatial shift of AOB/AOA amoA abundances in mangrove sediments, especially in the lower layer sediments. Except no hzo genes were detected at site S0-1, the obtained anammox hzo gene abundances ranged from $7.5 \times 10^{4}$ to $36.5 \times 10^{4}$ copies per gram of sediments (dry weight) (Fig. 3d). The hzo gene determined at sites S1 and $\mathrm{S} 0$ showed a significant higher copy number in surface layer samples than in lower layer samples $(p<0.05, n=3)$. However, in site S2, the surface layer sample had a lower hzo gene copy number than the lower layer sample $(p<$ $0.05, n=3)$.

Community distribution of $\mathrm{AOA}$ and $\mathrm{AOB}$ in mangrove sediments

Based on the $p$ values calculated by LIBSHUFF software, AOA showed similar community structure compositions only in samples collected at sites $\mathrm{S} 0-\mathrm{S}$ with $\mathrm{S} 1-\mathrm{s}$ or in samples collected at sites S0-s with S2-s (95\% confidence), while they were significantly different for any other two clone libraries as judged from pairwise comparison, indicating an obvious shift of AOA community structure in mangrove sediments (Table 2). However, for AOB community structures, there was a significant compositional overlap among the six bacterial amoA clone libraries $(95 \%$ confidence). Sites S0 and S1 for both surface and lower layers also showed similar bacterial amoA compositions 


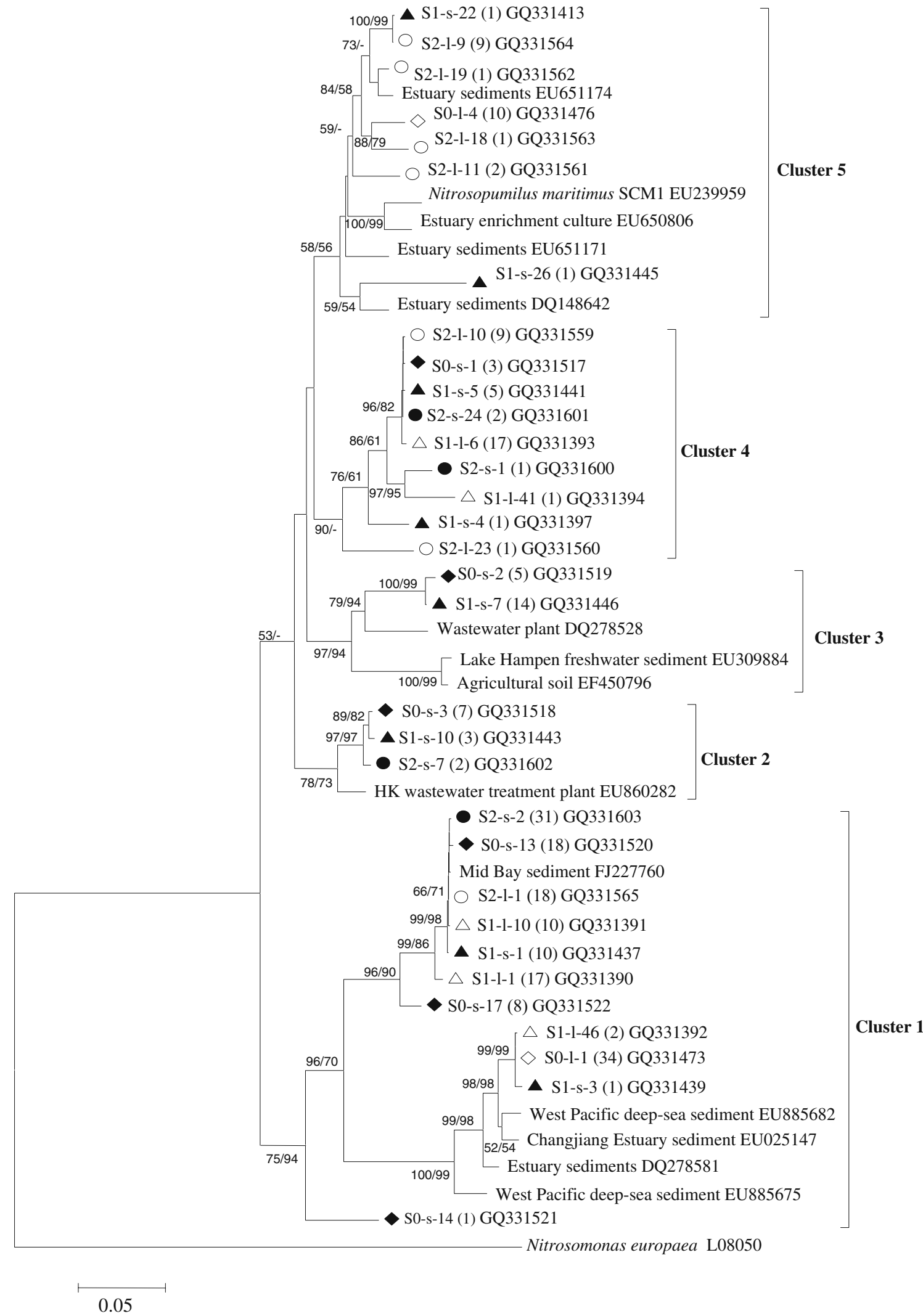

Fig. 1 Phylogenetic tree of archaeal amoA genes from surface (solid) and lower layers (open) mangrove sediments collected from the locations at immediately to the mangrove trees $(S O), 10 \mathrm{~m}(S 1)$, and $1,000 \mathrm{~m}(S 2)$ away from mangrove trees. Bootstrap values $(>50 \%)$ are indicated at branch points, with distance bootstrap values at front and parsimony values at back. Branch lengths correspond to sequence differences as indicated by the scale bar 
Fig. 2 Phylogenetic tree of bacterial amo $A$ genes from surface (solid) and lower layers (open) mangrove sediments collected from the locations at immediately to the mangrove trees $(S 0), 10 \mathrm{~m}(S 1)$, and $1,000 \mathrm{~m}(\mathrm{~S} 2)$ away from mangrove trees. Bootstrap values $(>50 \%)$ are indicated at branch points, with distance bootstrap values at front and parsimony values at back. Branch lengths correspond to sequence differences as indicated by the scale bar

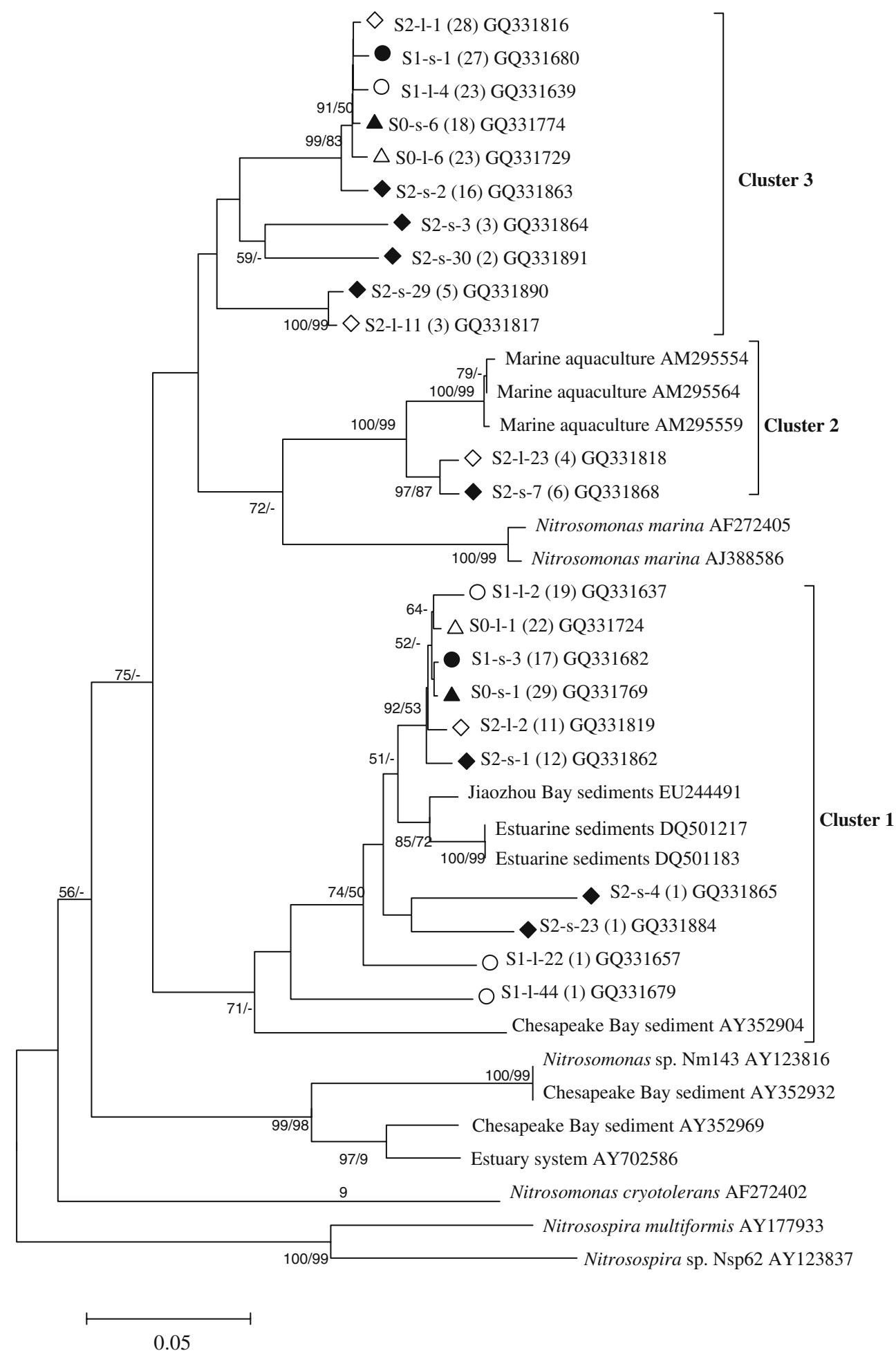

which further supported a uniform AOB community structure at this research area (Table 2). However, PCoA (data not shown) and Jackknife Environment Clusters separated the AOA communities into slightly distinct surface and lower layer groups while $\mathrm{AOB}$ communities were separated into groups by distances of being near and far away from mangrove trees groups (Fig. 4).
Correlations of ammonia-oxidizer community structures with environmental factors and anammox bacteria communities

Pearson's moment correlation analysis was used to find out whether there were some environmental factors affecting the distributions of AOA and $\mathrm{AOB}$ in mangrove sediments 

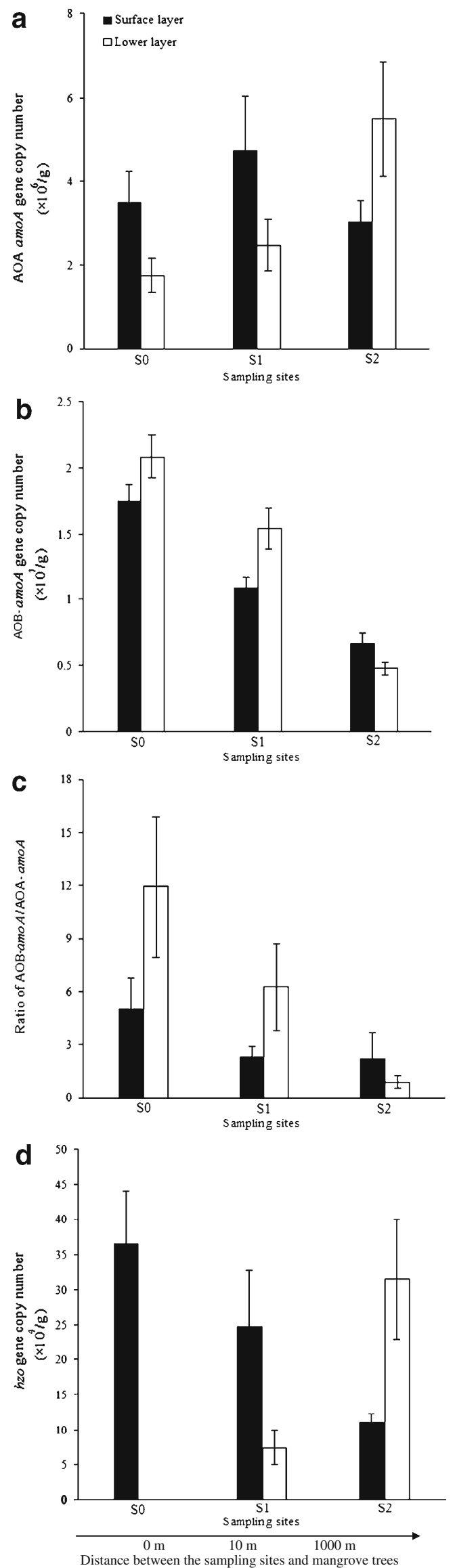

Fig. 3 Abundances of amoA gene copies of AOA (a), AOB (b), AOB amoA/AOA amoA abundance ratio (c), and hzo gene copies (d) of anammox bacteria in sediments

(Table 3). Results showed that the diversity and abundance of archaeal amoA sequences were significantly correlated with the $\mathrm{NH}_{4}{ }^{+}$while presence of bacterial amo $A$ was strongly correlated with the distances between sampling sites to mangrove trees and salinity. In addition, abundances of archaeal and bacterial amoA genes and their ratios were also significantly correlated with sediment $\mathrm{pH}$. Furthermore, it was found that AOA diversity and abundance were strongly and positively correlated with the copy number of anammox bacteria hzo genes (Table 3).

\section{Discussion}

In the present study, we draw a comprehensive picture about the diversity, distribution and abundances of AOA and $\mathrm{AOB}$ in mangrove sediments. Diversity estimations indicated that both archaeal and bacterial richness $(0.53-1.60$ and $0.66-1.70$ predicted by Shannon index, and $0.24-0.74$ and $0.20-0.52$ predicted by Simpson index) were within the ranges reported at other estuaries (0.44-2.12 and 0.33-2.02 for Shannon index; 0.10-0.84 and $0.11-0.84$ for Simpson index) (Beman and Francis 2006; Mosier and Francis 2008; Santoro et al. 2008) (Table 1). However, phylogenetic analysis showed that both the distributions of archaeal and of bacterial amo $A$ sequences supported that distinct phylogenetic groups in mangrove sediment and sequences in the distinct groups are less than $88 \%$ and $89 \%$ identified to other available sequences, which provides new information about AOA diversity and distribution in natural ecosystem (Figs. 1 and 2). However, the presence of the AOA sequences related to sequences found previously in samples taken from wastewater treatment plants of Hong Kong and the presence of $\mathrm{AOB}$ amoA sequences related to sequences found in Hong Kong marine aquaculture indicated that $\mathrm{AOA}$ and $\mathrm{AOB}$ in mangrove sediments of Mai Po Nature Reserve might also originate from the export of municipal wastes of the nearby area since large quantities of wastewater from domestic and industrial origins (including aquaculture) are discharged each year into Mai Po Nature Reserve without proper treatment (Wang et al. 2006).

From the abundances of $\mathrm{AOA}$ and $\mathrm{AOB}$ in mangrove sediments (Fig. 3), we found that AOA abundances in Mai Po Nature Reserve were similar to those in the San Francisco Bay estuary (Mosier and Francis 2008), while AOB abundances were slightly higher than those in salt 
Table 2 Comparisons of the archaeal and bacterial amoA genes clone libraries in mangrove ecosystem

\begin{tabular}{|c|c|c|c|c|c|c|c|}
\hline \multirow[t]{2}{*}{ Groups } & \multirow[t]{2}{*}{ Homologous library $X$ site } & \multicolumn{6}{|c|}{$p$ value for heterologous library $Y$ site } \\
\hline & & S0-s & S0-1 & S1-s & S1-1 & S2-s & S2-1 \\
\hline \multirow[t]{6}{*}{$\mathrm{AOA}$} & $\mathrm{S} 0$-s & & 0.001 & 0.007 & 0.001 & 0.002 & 0.001 \\
\hline & S0-1 & 0.001 & & 0.006 & 0.001 & 0.001 & 0.001 \\
\hline & S1-s & 0.060 & 0.001 & & 0.001 & 0.001 & 0.001 \\
\hline & S1-1 & 0.007 & 0.001 & 0.610 & & 0.001 & 0.001 \\
\hline & S2-s & 0.659 & 0.001 & 0.150 & 0.116 & & 0.003 \\
\hline & S2-1 & 0.001 & 0.001 & 0.030 & 0.001 & 0.001 & \\
\hline \multirow[t]{6}{*}{$\mathrm{AOB}$} & $\mathrm{S} 0$-s & & 0.002 & 0.008 & 0.009 & 0.007 & 0.104 \\
\hline & S0-1 & 0.012 & & 0.009 & 0.016 & 0.005 & 0.103 \\
\hline & S1-s & 0.005 & 0.001 & & 0.002 & 0.006 & 0.058 \\
\hline & S1-1 & 0.121 & 0.001 & 0.014 & & 0.023 & 0.087 \\
\hline & S2-s & 0.001 & 0.001 & 0.001 & 0.001 & & 0.012 \\
\hline & S2-1 & 0.002 & 0.005 & 0.002 & 0.002 & 0.005 & \\
\hline
\end{tabular}

When comparing multiple libraries, the LIBSHUFF $p$ values were compared with the critical value to insure whether the libraries are different or not. The critical value is calculated from the relationship: $p=1-(1-a)^{k(k-1)}$, where $p$ is the experimentwise $p$ value of $0.05, a$ is the critical $p$ value, and $k$ is the number of libraries. Thus, the critical $p$ value is $a=0.0017$ for the six clone libraries analyzed in the present study. For each pairwise comparison, if both two $p$ values calculated by LIBSHUFF are higher than $a(0.0017)$, the result indicates that there is no significant difference in the composition of the communities for the two compared clone libraries $(95 \%$ confidence). $p$ values set in italics indicate the two clone libraries with pairwise comparison that were not significantly different

marsh and coastal aquifer sediments $\left(10^{4} \sim 10^{6}\right.$ copies per gram sediment) (Dollhopf et al. 2005; Santoro et al. 2008). However, in contrast to numerous recent studies suggesting that AOA were more abundant than $\mathrm{AOB}$ in marine and terrestrial ecosystems (Leininger et al. 2006; Wuchter et al. 2006; Lam et al. 2007; Mincer et al. 2007; Beman et al. 2008), AOB amoA copy numbers were greater than that of AOA amoA in mangrove sediments except in the lower layer of S2 $(p<0.05$, ANOVA). Furthermore, AOB abundances were more abundant in the vicinity of the mangrove trees, where AOB abundan-
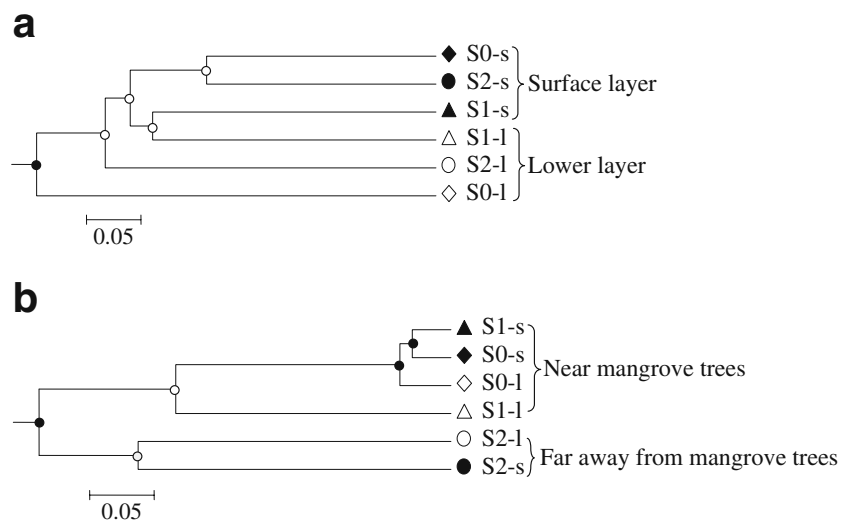

Fig. 4 Trees based on the UniFrac metric of archaeal (a) and bacterial (b) amo $A$ genes diversity, including sequence abundance data. Solid circles $>90 \%$; open circles $>50 \%$ ces decreased from $\mathrm{S} 0$ to $\mathrm{S} 2$, while AOA abundances increased at the same transect (except S2-s, $p<0.05$, ANOVA). These results might have two indications. One is that $\mathrm{AOB}$ might play a more important role in the nitrification in mangrove sediments than AOA and the other is that mangrove trees might have strong interactions with AOA and AOB, which strongly affected their distributions in mangrove sediments.

It has been reported that ammonia oxidizers often exhibit strong spatial structure distribution in estuaries. Studies in the Bahía del Tóbari and San Francisco Bay estuaries have shown that AOA communities differ between the interior and the mouth of the bays (Beman and Francis 2006; Mosier and Francis 2008). AOB communities shifted along salinity gradients in the Chesapeake Bay, Plum Island Sound and Ythan estuaries (Francis et al. 2003; Bernhard et al. 2005; Freitag et al. 2006). In the present study, AOA communities had little compositional overlap in surface layer sediments ( $\mathrm{S} 0$-s vs S1-s and S0-s vs S2-s) but were significantly different in lower layers and their compositions could be divided into slightly distinct groups based on sediments collected from surface or lower layers (Fig. 4a). However, communities of AOB overlapped significantly at both surface and lower layer sediment samples, and were clearly separated into two groups according the distances of sites location from mangrove trees (Fig. 4b). Together the abundance variations of $\mathrm{AOA}$ and $\mathrm{AOB}$ in mangrove sediments and the distinct spatial patterns for $\mathrm{AOA}$ and $\mathrm{AOB}$ communities in 
Table 3 Statistical analysis of AOA and AOB community structures with physicochemical parameters and anammox bacteria communities

\begin{tabular}{|c|c|c|c|c|c|c|c|c|c|c|}
\hline \multirow[t]{3}{*}{ Parameter } & \multicolumn{10}{|c|}{ Pearson's moment correlation } \\
\hline & \multicolumn{2}{|l|}{ OTUs } & \multicolumn{2}{|c|}{ Shannon index } & \multicolumn{2}{|c|}{ Simpson index } & \multicolumn{2}{|c|}{ Abundance } & \multicolumn{2}{|c|}{ amo $A$ genes abundance ratio } \\
\hline & $\mathrm{AOA}$ & $\mathrm{AOB}$ & AOA & AOB & $\mathrm{AOA}$ & AOB & $\mathrm{AOA}$ & AOB & $\mathrm{AOB} / \mathrm{AOA}$ & $\log (\mathrm{AOB} / \mathrm{AOA})$ \\
\hline Depth & -0.41 & 0.36 & -0.33 & 0.29 & 0.13 & -0.35 & -0.20 & 0.17 & 0.43 & 0.18 \\
\hline Distance & -0.11 & $0.86^{*}$ & -0.19 & $0.93^{*}$ & 0.29 & $-0.91^{*}$ & 0.43 & $-0.86^{*}$ & -0.62 & -0.76 \\
\hline Temperature & 0.64 & 0.03 & 0.60 & 0.13 & -0.41 & -0.08 & 0.64 & -0.52 & -0.76 & -0.62 \\
\hline Redox & 0.03 & -0.55 & 0.01 & -0.56 & 0.12 & 0.62 & -0.32 & 0.26 & 0.01 & 0.32 \\
\hline $\mathrm{pH}$ & 0.75 & 0.42 & 0.66 & 0.51 & -0.52 & -0.50 & $0.96^{*}$ & $-0.84^{*}$ & $-0.92^{*}$ & $-0.95^{*}$ \\
\hline $\mathrm{NH}_{4}^{+}$ & $0.93 *$ & 0.19 & $0.88^{*}$ & 0.26 & $-0.81 *$ & -0.27 & $0.97 *$ & -0.58 & -0.76 & -0.78 \\
\hline $\mathrm{NO}_{3}^{-}$ & 0.07 & -0.10 & -0.07 & -0.03 & 0.28 & 0.09 & 0.04 & -0.34 & -0.42 & -0.22 \\
\hline $\mathrm{NO}_{2}^{-}$ & -0.34 & 0.48 & -0.53 & 0.45 & 0.65 & -0.39 & -0.12 & -0.55 & -0.38 & -0.28 \\
\hline $\mathrm{NO}_{3}{ }^{-}+\mathrm{NO}_{2}{ }^{-}$ & -0.22 & 0.31 & -0.40 & 0.31 & 0.57 & -0.25 & -0.07 & -0.52 & -0.43 & -0.29 \\
\hline Salinity & 0.02 & $0.90 *$ & -0.13 & $0.91 *$ & 0.21 & $-0.88^{*}$ & 0.47 & $-0.93 *$ & -0.72 & $-0.81^{*}$ \\
\hline hzo abundance & $0.81 *$ & 0.08 & $0.88 *$ & 0.15 & $-0.82 *$ & -0.14 & $0.81 *$ & -0.36 & -0.65 & -0.59 \\
\hline
\end{tabular}

${ }^{*} p<0.05$, which is typically regarded as significant, as determined by Excel function TDIST from the $t$ value given by the following equation: $t=\times \sqrt{\frac{n-2}{\left(1-r^{2}\right)}}$. The number of samples is given by $n$

a Pearson's moment correlation $(r)$ was determined by using the following equation: $r=\frac{n\left(\sum X Y\right)-\left(\sum X\right)\left(\sum Y\right)}{\sqrt{\left[n \sum X^{2}-\left(\sum X\right)^{2}\right]\left[n \sum Y^{2}-\left(\sum Y\right)^{2}\right]}}$

mangrove sediments further confirm that the existence of mangrove trees might have strong influences on the distribution of $\mathrm{AOA}$ and $\mathrm{AOB}$ in both diversity and abundances. In previous researches, it has been shown that the presence of some plants, such as the freshwater macrophyte Littorella uniflora (Herrmann et al. 2008), rice (Chen et al. 2008), Spartina alterniflora, or Spartina patens (Moin et al. 2009) has strong influences on the diversity and abundance of AOA and AOB. Furthermore, the plants-nutrient-microorganisms interaction model in mangrove ecosystems has been presented in a previous study (Holguin et al. 2001); here, the strong influences of mangrove trees on AOA and $\mathrm{AOB}$ community structures and the significant correlations of the AOA diversity and abundance with the distance of sampling sites to mangrove trees might also give strong evidence on this model (Table 3).

Interactions between nitrifiers (AOA and $\mathrm{AOB}$ ) and anammox bacteria had been recorded in the Black Sea (Lam et al. 2007) and in the Peruvian oxygen minimum zone (Lam et al. 2009), where nitrifiers were proposed to supply the nitrite to anammox to form a nitrification-anammox coupling. The significantly and positively correlations between AOA diversity and abundance with the anammox bacteria hzo gene abundances might also indicate that the complex interactions not only exist among microorganisms and mangrove forest but also within different N-transforming microorganisms. However, no similar relationships were found in between $\mathrm{AOB}$ and anammox bacteria, which indicated that $\mathrm{AOB}$ communities might be also affected by other environmental factors, such as salinity. Indeed, AOB diversity and abundances were found to be significantly correlated with salinity. Since salinity is a particularly important parameter for ammonia oxidation in coastal and estuary sediments, in part because of its influence on $\mathrm{NH}_{4}{ }^{+}$ adsorption in sediments (Boatman and Murray 1982; Boynton and Kemp 1985), it is thus reasonable that salinity has a strong influence on AOB which might be more important on nitrification in mangrove sediments. In addition, a positive correlation between $\mathrm{AOA}$ abundance and $\mathrm{pH}$, and negative correlations between $\mathrm{AOB}$ abundance and AOB amoA/AOA amoA ratios with $\mathrm{pH}$ were found in the present study, indicating that sediment $\mathrm{pH}$ is also an important factor affecting the abundances of AOA and AOB in mangrove sediments (Table 3).

In conclusion, unique phylogenetic groups of archaeal and bacterial amoA genes were revealed in mangrove sediments, indicating site specific AOA and AOB occur in Mai Po mangrove sediments. The spatial distribution of $\mathrm{AOA}$ and $\mathrm{AOB}$ communities and abundances were strongly influenced by the presence of mangrove trees, nitrogen substrates, and anammox bacteria. Furthermore, the higher abundance of $\mathrm{AOB}$ than $\mathrm{AOA}$ indicated that $\mathrm{AOB}$ may play a more important role on nitrification in the mangrove sediment. The results provide more specific information on more effective use of mangrove wetlands as alternative biological systems for treatment of wastewater or surface run-off containing high inorganic nitrogen. 
Acknowledgements This research was supported in part by grants from Agriculture, Fisheries, and Conservation Department of the Hong Kong SAR Government, and Faculty of Science on Sustainable Water at The University of Hong Kong (to J-DG); National Natural Science Foundation of China (3080032), Knowledge Innovation Key Project of The Chinese Academy of Sciences (KZCX2-YW-QN207), Guangdong Province Natural Science Foundation (84510301001692), and a start-up fund for Excellent Scholarship of the Chinese Academy of Sciences (07YQ091001) (to Y-GH). We would like to thank Jessie Lai for laboratory support at The University of Hong Kong.

Open Access This article is distributed under the terms of the Creative Commons Attribution Noncommercial License which permits any noncommercial use, distribution, and reproduction in any medium, provided the original author(s) and source are credited.

\section{References}

Adair KL, Schwartz E (2008) Evidence that ammonia-oxidizing archaea are more abundant than ammonia-oxidizing bacteria in semiarid soils of northern Arizona, USA. Microb Ecol 56:420-426

American Public Health Association (1995) Standard methods for the examination of water and wastewater. APHA, Washington

Beman JM, Francis CA (2006) Diversity of ammonia-oxidizing archaea and bacteria in the sediments of a hypernutrified subtropical estuary: Bahia del Tobari, Mexico. Appl Environ Microbiol 72:7767-7777

Beman JM, Popp BN, Francis CA (2008) Molecular and biogeochemical evidence for ammonia oxidation by marine Crenarchaeota in the Gulf of California. ISME J 2:429-441

Bernhard AE, Donn T, Giblin AE, Stahl DA (2005) Loss of diversity of ammonia-oxidizing bacteria correlates with increasing salinity in an estuary system. Environ Microbiol 7:1289-1297

Boatman CD, Murray JW (1982) Modeling exchangeable $\mathrm{NH}_{4}^{+}$ adsorption in marine-sediments - process and controls of adsorption. Limnol Oceanogr 27:99-110

Boynton WR, Kemp WM (1985) Nutrient regeneration and oxygenconsumption by sediments along an estuarine salinity gradient. Mar Ecol-Prog Ser 23:45-55

Chen XP, Zhu YG, Xia Y, Shen JP, He JZ (2008) Ammonia-oxidizing archaea: important players in paddy rhizosphere soil? Environ Microbiol 10:1978-1987

Dang H, Zhang X, Sun J, Li T, Zhang Z, Yang G (2008) Diversity and spatial distribution of sediment ammonia-oxidizing crenarchaeota in response to estuarine and environmental gradients in the Changjiang Estuary and East China Sea. Microbiol 154:2084-2095

Dang H, Li J, Zhang X, Li T, Tian F, Jin W (2009) Diversity and spatial distribution of amoA-encoding archaea in the deep-sea sediments of the tropical West Pacific Continental Margin. J Appl Microbiol 106:1482-1493

de la Torre JR, Walker CB, Ingalls AE, Konneke M, Stahl DA (2008) Cultivation of a thermophilic ammonia oxidizing archaeon synthesizing crenarchaeol. Environ Microbiol 10:810-818

Dollhopf SL, Hyun JH, Smith AC, Adams HJ, O’Brien S, Kostka JE (2005) Quantification of ammonia-oxidizing bacteria and factors controlling nitrification in salt marsh sediments. Appl Environ Microbiol 71:240-246

Erguder TH, Boon N, Wittebolle L, Marzorati M, Verstraete W (2009) Environmental factors shaping the ecological niches of ammoniaoxidizing archaea. FEMS Microbiol Rev 33:855-869

Francis CA, O'Mullan GD, Ward BB (2003) Diversity of ammonia monooxygenase $(a m o A)$ genes across environmental gradients in Chesapeake Bay sediments. Geobiology 1:129-140

Francis CA, Roberts KJ, Beman JM, Santoro AE, Oakley BB (2005) Ubiquity and diversity of ammonia-oxidizing archaea in water columns and sediments of the ocean. Proc Natl Acad Sci U S A 102:14683-14688

Freitag TE, Chang L, Prosser JI (2006) Changes in the community structure and activity of betaproteobacterial ammonia-oxidizing sediment bacteria along a freshwater-marine gradient. Environ Microbiol 8:684-696

Hansel CM, Fendorf S, Jardine PM, Francis CA (2008) Changes in bacterial and archaeal community structure and functional diversity along a geochemically variable soil profile. Appl Environ Microbiol 74:1620-1633

Hatzenpichler R, Lebedeva EV, Spieck E, Stoecker K, Richter A, Daims H, Wagner M (2008) A moderately thermophilic ammonia-oxidizing crenarchaeote from a hot spring. Proc Natl Acad Sci U S A 105:2134-2139

Herrmann M, Saunders AM, Schramm A (2008) Archaea dominate the ammonia-oxidizing community in the rhizosphere of the freshwater macrophyte Littorella uniflora. Appl Environ Microbiol 74:3279-3283

Herrmann M, Saunders AM, Schramm A (2009) Effect of lake trophic status and rooted macrophytes on community composition and abundance of ammonia-oxidizing prokaryotes in freshwater sediments. Appl Environ Microbiol 75:3127-3136

Holguin G, Vazquez P, Bashan Y (2001) The role of sediment microorganisms in the productivity, conservation, and rehabilitation of mangrove ecosystems: an overview. Biol Fertil Soils 33:265-278

Konneke M, Bernhard AE, de la Torre JR, Walker CB, Waterbury JB, Stahl DA (2005) Isolation of an autotrophic ammonia-oxidizing marine archaeon. Nature 437:543-546

Kowalchuk GA, Stephen JR (2001) Ammonia-oxidizing bacteria: a model for molecular microbial ecology. Annu Rev Microbiol 55:485-529

Kristensen E, Jensen MH, Banta GT, Hansen K, Holmer M, King GM (1998) Transformation and transport of inorganic nitrogen in sediments of a southeast Asian mangrove forest. Aquat Microb Ecol 15:165-175

Lam P, Jensen MM, Lavik G, McGinnis DF, Müller B, Schubert CJ, Amann R, Thamdrup B, Kuypers MM (2007) Linking crenarchaeal and bacterial nitrification to anammox in the Black Sea. Proc Natl Acad Sci U S A 104:7104-7109

Lam P, Lavik G, Jensen MM, van de Vossenberg J, Schmid M, Woebken D, Gutierrez D, Amann R, Jetten MS, Kuypers MM (2009) Revising the nitrogen cycle in the Peruvian oxygen minimum zone. Proc Natl Acad Sci U S A 106:4752-4557

Leininger S, Urich T, Schloter M, Schwark L, Qi J, Nicol GW, Prosser JI, Schuster SC, Schleper C (2006) Archaea predominate among ammonia-oxidizing prokaryotes in soils. Nature 442:806-809

Li M, Hong Y, Klotz MG, Gu J-D (2010) A comparison of primer sets for detecting 16S rRNA and hydrazine oxidoreductase genes of anaerobic ammonium-oxidizing bacteria in marine sediments. Appl Microbiol Biotechnol 86:781-790

Lozupone C, Hamady M, Knight R (2006) UniFrac - an online tool for comparing microbial community diversity in a phylogenetic context. BMC Bioinformatics 7:371

Meyer RL, Risgaard-Petersen N, Allen DE (2005) Correlation between anammox activity and microscale distribution of nitrite in a subtropical mangrove sediment. Appl Environ Microbiol 71:6142-6149

Mincer TJ, Church MJ, Taylor LT, Preston C, Karl DM, DeLong EF (2007) Quantitative distribution of presumptive archaeal and bacterial nitrifiers in Monterey Bay and the North Pacific Subtropical Gyre. Environ Microbiol 9:1162-1175

Moin NS, Nelson KA, Bush A, Bernhard AE (2009) Distribution and diversity of archaeal and bacterial ammonia oxidizers in salt marsh sediments. Appl Environ Microbiol 75:7461-7468

Mosier AC, Francis CA (2008) Relative abundance and diversity of ammonia-oxidizing archaea and bacteria in the San Francisco Bay estuary. Environ Microbiol 10:3002-3016 
Park HD, Wells GF, Bae H, Criddle CS, Francis CA (2006) Occurrence of ammonia-oxidizing archaea in wastewater treatment plant bioreactors. Appl Environ Microbiol 72:5643-5647

Prosser JI, Embley TM (2002) Cultivation-based and molecular approaches to characterisation of terrestrial and aquatic nitrifiers. Antonie Van Leeuwenhoek 81:165-179

Purkhold U, Pommerening-Roser A, Juretschko S, Schmid MC, Koops HP, Wagner M (2000) Phylogeny of all recognized species of ammonia oxidizers based on comparative $16 \mathrm{~S}$ rRNA and $a m o A$ sequence analysis: implications for molecular diversity surveys. Appl Environ Microbiol 66:5368-5382

Purvaja R, Ramesh R, Ray AK, Rixen T (2008) Nitrogen cycling: A review of the processes, transformations and fluxes in coastal ecosystems. Curr Sci 94:1419-1438

Rivera-Monroy VH, Twilley RR (1996) The relative role of denitrification and immobilization in the fate of inorganic nitrogen in mangrove sediments (Terminos Lagoon, Mexico). Limnol Oceanogr 41:284-296

Rotthauwe JH, Witzel KP, Liesack W (1997) The ammonia monooxygenase structural gene amoA as a functional marker: molecular fine-scale analysis of natural ammonia-oxidizing populations. Appl Environ Microbiol 63:4704-4712

Santoro AE, Francis CA, de Sieyes NR, Boehm AB (2008) Shifts in the relative abundance of ammonia-oxidizing bacteria and archaea across physicochemical gradients in a subterranean estuary. Environ Microbiol 10:1068-1079

Schloss PD, Handelsman J (2005) Introducing DOTUR, a computer program for defining operational taxonomic units and estimating species richness. Appl Environ Microbiol 71:1501-1506

Schmid MC, Hooper AB, Klotz MG, Woebken D, Lam P, Kuypers MM, Pommerening-Roeser A, Op den Camp HJ, Jetten MS (2008) Environmental detection of octahaem cytochrome c hydroxylamine/hydrazine oxidoreductase genes of aerobic and anaerobic ammonium-oxidizing bacteria. Environ Microbiol 10:3140-3149

Shimamura M, Nishiyama T, Shigetomo H, Toyomoto T, Kawahara Y, Furukawa K, Fujii T (2007) Isolation of a multiheme protein with features of a hydrazine-oxidizing enzyme from an anaerobic ammonium-oxidizing enrichment culture. Appl Environ Microbiol 73:1065-1072

Singleton DR, Furlong MA, Rathbun SL, Whitman WB (2001) Quantitative comparisons of 16S rRNA gene sequence libraries from environmental samples. Appl Environ Microbiol 67:43744376
Sjoling S, Mohammed SM, Lyimo TJ, Kyaruzi JJ (2005) Benthic bacterial diversity and nutrient processes in mangroves: impact of deforestation. Estuar Coast Shelf Sci 63:397-406

Steger D, Ettinger-Epstein P, Whalan S, Hentschel U, de Nys R, Wagner M, Taylor MW (2008) Diversity and mode of transmission of ammonia-oxidizing archaea in marine sponges. Environ Microbiol 10:1087-1094

Strous M, Pelletier E, Mangenot S, Rattei T, Lehner A, Taylor MW, Horn M, Daims H, Bartol-Mavel D, Wincker P, Barbe V, Fonknechten N, Vallenet D, Segurens B, Schenowitz-Truong C, Medigue C, Collingro A, Snel B, Dutilh BE, Op den Camp HJ, van der Drift C, Cirpus I, van de Pas-Schoonen KT, Harhangi HR, van Niftrik L, Schmid M, Keltjens J, van de Vossenberg J, Kartal B, Meier H, Frishman D, Huynen MA, Mewes HW, Weissenbach J, Jetten MS, Wagner M, Le Paslier D (2006) Deciphering the evolution and metabolism of an anammox bacterium from a community genome. Nature 440:790-794

Tamura K, Dudley J, Nei M, Kumar S (2007) MEGA4: Molecular Evolutionary Genetics Analysis (MEGA) software version 4.0. Mol Biol Evol 24:1596-1599

Urakawa H, Tajima Y, Numata Y, Tsuneda S (2008) Low temperature decreases the phylogenetic diversity of ammonia-oxidizing archaea and bacteria in aquarium biofiltration systems. Appl Environ Microbiol 74:894-900

Wang Y, Leung PC, Qian PY, Gu J-D (2006) Antibiotic resistance and plasmid profile of environmental isolates of Vibrio species from Mai Po Nature Reserve, Hong Kong. Ecotoxicol 15:371-378

Wong YS, Tam NFY, Lan CY (1997) Mangrove wetlands as wastewater treatment facility: a field trial. Hydrobiologia 352:49-59

Wuchter C, Abbas B, Coolen MJ, Herfort L, van Bleijswijk J, Timmers P, Strous M, Teira E, Herndl GJ, Middelburg JJ, Schouten S, Sinninghe Damste JS (2006) Archaeal nitrification in the ocean. Proc Natl Acad Sci U S A 103:12317-12322

Zhang CL, Ye Q, Huang Z, Li W, Chen J, Song Z, Zhao W, Bagwell C, Inskeep WP, Ross C, Gao L, Wiegel J, Romanek CS, Shock EL, Hedlund BP (2008) Global occurrence of archaeal amoA genes in terrestrial hot springs. Appl Environ Microbiol 74:6417-6426

Zhang T, Jin T, Yan Q, Shao M, Wells G, Criddle C, PF HH (2009) Occurrence of ammonia-oxidizing archaea in activated sludges of a laboratory scale reactor and two wastewater treatment plants. J Appl Microbiol 107:970-977

Zhu T, Sikora FJ (1995) Ammonium and nitrate removal in vegetated and unvegetated gravel bed microcosm wetlands. Water Sci Technol 32:219-228 